\title{
Bringing endocrine basic science and physician investigators together
}

Magnus R. Dias da Silva', Alexander A. L. Jorge²

$\mathrm{O}$

ver the last decades an explosive increase in basic endocrine science, especially in molecular genetics, and its translational application to patients had a profound impact on endocrine clinical management. In view of this rapid progress in endocrinology and metabolism, ABE\&M have launched a second special edition of "Clinical \& Molecular Endocrine (C\&M) Case Reports" to attract more physician readers to this growing field. In addition, focusing on molecular case reports that were followed by different expert groups of all recognized endocrinology subspecialties can help ABE\&M achieve one of its missions in continuing education, a commitment invigorated by the first C\&M in 2008 (1).

Most of the molecular medicine approaches were thought to be almost exclusive to basic research scientists, but lately these have been progressively extended to physicians. On the one hand, the clinical field profits from scientific advances; on the other hand, clinical observations frequently nourish questions for further investigation, sprouting answers that have important influence on basic science. These molecular approaches comprise human DNA, RNA and protein assays envisioning more accurate diagnosis or prognosis markers of endocrine genetic disorders, mostly using molecular biology tools. Not only may these tools help establish molecular aetiology but also broaden the understanding of pathophysiological mechanisms, target individualized medication (farmacogenomics), identify primary prevention and pre-natal intervention. Undoubtedly, these advances in molecular endocrinology must grow together with ethics in view of offering the best possible genetic counseling practice.

In 2008, ABE\&M offered the first round of molecular case reports in a way our reader would become more interested: how to take care of a patient in face of a particular molecular diagnosis. Proudly, C\&M 2008 has been showing great scientific repercussion worldwide. These peer-reviewed original articles were cited by many different international endocrine Journals, as many as 75\%. For instance, the work of Piccoli and cols., 2008 has been cited 5 times within two years (2). In general, we observed that the last edition reached 1.5 citation per article, a performance $50 \%$ greater than other editions in the same period. Several other articles received 3 or 4 citations and deserve our recognition (3-9).

Among the articles cited abroad within the same period, 8 were referenced more than 3 times, which is a promising sign of ABE\&M's most recent growth. We hope we will continuously thrive - a challenge beyond any ulterior interest and that strongly relies on the commitment of ABE\&M editorial members, authors, and particularly reviewers.

We welcome you with the C\&M2010 to get the best of the following 17 peerreviewed articles and 1 review (10), reassuming our mission of bringing basic science and physician investigators together; therefore, translating these findings to better

${ }^{1}$ Assistant Professor

Laboratório de Endocrinologia Molecular e Translacional,

Departamento de Medicina, Universidade Federal de São Paulo, Escola Paulista de Medicina (Unifesp/EPM), São Paulo, SP, Brazil ${ }^{2}$ Associate Professor

LIM-25, Faculdade de Medicina da Universidade de São Paulo (FMUSP), SP, Brazil

Correspondência para: Magnus R. Dias da Silva Laboratório de Endocrinologia Molecular e Translacional, Universidade Federal de São Paulo Rua Pedro de Toledo, 669, $11^{\circ}$ andar

04039-032 - São Paulo, SP, Brazil silvamagnus@gmail.com 
assist our patients. The articles are diverse and reflect the maturity and expertise of our scientists who have provided their best resources of molecular diagnosis and assistance to patients.

We would like to express our deep gratitude to the authors, who submitted their reports, to the reviewers, who carefully pointed out opportunities for improvement, to the ABE\&M office coworkers and editing board, who have given their best to meet the highest standards. We also hope our readers will agree and take advantage of these following readings.

\section{REFERENCES}

1. Dias da Silva MR. Getting your report seen in and beyond ABE\&M. Arq Bras Endocrinol Metabol. 2008;52(8):1203-4.

2. Piccoli JC, Gottlieb MG, Castro L, Bodanese LC, Manenti ER, Bogo MR, et al. Association between 894G>T endothelial nitric oxide synthase gene polymorphisms and metabolic syndrome. Arq Bras Endocrinol Metabol. 2008;52(8):1367-73.

3. Funari MF, Jorge AA, Pinto EM, Arnhold IJ, Mendonca BB, Nishi MY. Cryptic intragenic deletion of the SHOX gene in a family with Leri-Weill dyschondrosteosis detected by Multiplex LigationDependent Probe Amplification (MLPA). Arq Bras Endocrinol Metabol. 2008;52(8):1382-7.
4. Della MannaT, Battistim C, Radonsky V, Savoldelli RD, Damiani D, Kok F, et al. Glibenclamide unresponsiveness in a Brazilian child with permanent neonatal diabetes mellitus and DEND syndrome due to a C166Y mutation in KCNJ11 (Kir6.2) gene. Arq Bras Endocrinol Metabol. 2008;52(8):1350-5.

5. Vieira Neto L, Taboada GF, Gadelha MR. Somatostatin receptors subtypes 2 and 5, dopamine receptor type 2 expression and gsp status as predictors of octreotide LAR responsiveness in acromegaly. Arq Bras Endocrinol Metabol. 2008;52(8):1288-95.

6. Nishi MY, Correa RV, Costa EM, Billerbeck AE, Cruzes AL, Domenice $S$, et al. Tall stature and poor breast development after estrogen replacement in a hypergonadotrophic hypogonadic patient with a 45,X/46,X,der(X) karyotype with SHOX gene overdosage. Arq Bras Endocrinol Metabol. 2008;52(8):1282-7.

7. Diniz ET, Jorge AA, Arnhold IJ, Rosenbloom AL, Bandeira F. [Novel nonsense mutation ( $p . Y 113 X$ ) in the human growth hormone receptor gene in a Brazilian patient with Laron syndrome]. Arq Bras Endocrinol Metabol. 2008;52(8):1264-71.

8. Macedo LC, Soardi FC, Ananias N, Belangero VM, Rigatto SZ, De-Mello MP, et al. Mutations in the vitamin $D$ receptor gene in four patients with hereditary 1,25-dihydroxyvitamin D-resistant rickets. Arq Bras Endocrinol Metabol. 2008;52(8):1244-51.

9. Andrade JG, Guaragna MS, Soardi FC, Guerra-Junior G, Mello MP, Maciel-Guerra AT. Clinical and genetic findings of five patients with WT1-related disorders. Arq Bras Endocrinol Metabol. 2008;52(8):1236-43.

10. Rolim AL, Lindsey SC, Kunii IS, Fujikawa AM, Soares FA, Chiamolera $\mathrm{MI}$, et al. Ion channelopathies in endocrinology: recent genetic findings and pathophysiological insights. Arq Bras Endocrinol Metabol. 2010;54(8):673-81. 